УдК 616.314.15-002-74

DOI 10.11603/2311-9624.2018.4.9746

\author{
(CB. І. Войтович ${ }^{1}$, М. Ю. Гончарук-Хомин ${ }^{1}$, О. Є. Костенко ${ }^{1}$, О. В. Савчук ${ }^{1}$, Іззет Явуз $^{2}$ \\ ДВН3 «Ужгородський національний університет» ${ }^{1}$ \\ Університет Дікле, Діярбакир, Туреччина ${ }^{2}$ \\ (myroslav.goncharuk-khomyn@uzhnu.edu.ua)
}

\title{
Вплив фактора конфігурації порожнини зуба на прогноз функціонування композитної реставрації
}

Резюме. Розробка параметра конфігурації порожнини була обгрунтована потребою квантифікації співвідношення показників полімеризаційної усадки та полімеризаційного стресу відповідно до особливостей геометрії відпрепарованого каріозного дефекту. Однак за даними різних досліджень, рівень розподілу полімеризаційного стресу вираженіше залежить від абсолютних розмірів досліджуваних зразків реставрацій, а не безпосередньо від показника С-фактора, що проте не було достатньою мірою доказово інтерпретовано з точки зору клінічної значимості отриманих результатів.

Мета дослідження - проаналізувати вплив фактора конфігурації відпрепарованої порожнини на успішність функціонування прямих реставрацій у процесі розробки моделі прогностичної оцінки розподілу напруг на межі інтерфейсу композитного матеріалу та тканин зуба.

Матеріали і методи. Для проведення пошуку використовували форму пошуку Google Scholar (http:// scholar.google.com) із застосуванням їі розширених функцій. У результаті застосування операторів «пошук за фразою» та "в заголовку» були сформовані наступні набори ключових слів: «C-factor», «dental cavity configuration», «cavity geometry», «direct restoration», «composite restoration», які використовували у різних комбінаціях. Кожен отриманий результат пошуку за комбінацією ключових слів являв собою набір академічних робіт відповідної тематики, які в подальшому підлягали контент-аналізу.

Результати досліджень та їх обговорення. Виходячи із наведених літературних даних, було підтверджено, що зменшення рівня усадкового стресу при зростанні кількісного показника С-фактора та зниження прогностичного показника успішності композитної реставрації при аналогічній тенденції. Показники С-фактора у діапазоні 0,3-2,3 не є гранично критичними з точки зору ризику формування мікропроміжку між композитом та стінкою зуба порівняно із показниками С-фактора, що наближаються до 3,0.

Висновки. Подальша розробка складної моделі скінчених елементів із репрезентацією у їі структурі елементів різної щільності (зокрема емалі, дентину, різних композитних та прокладочних матеріалів) та відповідною математичною аргументацією векторів полімеризаційної усадки та стресу, дозволить об'єктивізувати кумулятивний вплив показника С-фактора на успішність функціонування композитної реставрації, виходячи із полінаправленості напруг на межі бондингового інтерфейсу композитного матеріалу та тканин зуба.

Ключові слова: С-фактор; композитна реставрація; конфігурація порожнини.

\author{
(СВ. И. Войтович ${ }^{1}$, М. Ю. Гончарук-Хомин ${ }^{1}$, А. Е. Костенко ${ }^{1}$, О. В. Савчук ${ }^{1}$, \\ Иззэт Явуз ${ }^{2}$
}

ГВУЗ «Ужгородский национальный университет» ${ }^{1}$

Университет Дикле, Диярбакыр, Турция ${ }^{2}$

\section{Влияние фактора конфигурации полости зуба на прогноз функционирования композитной реставрации}

Резюме. Разработка параметра конфигурации полости была обоснована необходимостью квантификации соотношения показателей полимеризационной усадки и полимеризационного стресса в соответствии с особенностями геометрии отпрепарованного кариозного дефекта. Однако по данным различных исследований, уровень распределения полимеризационного стресса более выражено зависит от абсолютных размеров исследуемых образцов реставраций, а не непосредственно от показателя С-фактора, что однако не было в достаточной мере доказательно интерпретировано с точки зрения клинической значимости полученных результатов.

Цель исследования - проанализировать влияние фактора конфигурации отпрепарированной полости на успешность функционирования прямых реставраций в процессе разработки модели про- 
гностической оценки распределения напряжений на границе интерфейса композитного материала и тканей зуба.

Материалы и методы. Для проведения поиска использовалась форма поиска Google Scholar (http:// scholar.google.com) с применением ее расширенных функций. В результате использования операторов «поиск по фразе» и «в заголовке» были сформированы следующие наборы ключевых слов: "C-factor», "dental cavity configuration», "cavity geometry", «direct restoration", "composite restoration", которые применялись в различных комбинациях. Каждый полученный результат поиска по комбинации ключевых слов представлял собой набор академических работ соответствующей тематики, которые в дальнейшем подлежали контент-анализу.

Результаты исследований и их обсуждение. Исходя из приведенных литературных данных, был подтвержден факт уменьшения уровня усадочного стресса при росте количественного показателя С-фактора и снижение прогностического показателя успешности композитной реставрации при аналогичной тенденции. Показатели С-фактора в диапазоне 0,3-2,3 не являются предельно критическими с точки зрения риска формирования микрозазора между композитом и стенкой зуба по сравнению с показателями С-фактора, приближающихся к 3,0.

Выводы. Дальнейшая разработка сложной модели конечных элементов с репрезентацией в ее структуре элементов различной плотности (в частности эмали, дентина, различных композитных и прокладочных материалов) и соответствующей математической аргументацией векторов полимеризационной усадки и стресса, позволит объективизировать кумулятивное воздействие показателя С-фактора на успешность функционирования композитной реставрации, исходя из полинаправлености напряжений на границе бондингового интерфейса композитного материала и тканей зуба.

Ключевые слова: С-фактор; композитная реставрация; конфигурация полости.

\author{
(C). I. Voytovich ${ }^{1}$, M. Yu. Goncharuk-Khomyn ${ }^{1}$, O. E. Kostenko ${ }^{1}$, O. V. Savchuk ${ }^{1}$, \\ Izzet Yavuz ${ }^{2}$ \\ Uzhhorod National University ${ }^{1}$ \\ Dicle University, Diyarbakir, Turkey²
}

\title{
Influence of the dental cavity configuration factor on the prediction of the composite restoration function
}

Summary. The development of the cavity configuration factor was substantiated by the necessity of quantifying the ratio of polymerization shrinkage and polymerization stress indicators in accordance with the peculiarities of the geometry of prepared carious defect. However, according to various studies, the level of distribution of polymerization stress more strongly depends on the absolute sizes of the investigated restoration samples, and not directly on the C-factor, however, it has not been adequately evidently interpreted from the point of view of the clinical significance for the obtained results.

The aim of the study - to analyze the effect of the configuration factor of the prepared cavity on the success of the direct restorations function in the process of developing a model of predictive assessment of stress distribution at the interface of composite material and tooth tissues.

Materials and Methods. Google Scholar search form (http://scholar.google.com) was used with its advanced features for realization of study objective. The following sets of words "C-factor», «dental cavity configuration", "cavity geometry", "direct restoration", and "composite restoration» were used as header operators in various combinations, each resulting for the search of keywords combination represented as a set of academic papers on relevant topics, that were subsequently subject to content analysis.

Results and Discussion. Based on the literature data, the reduction of shrinkage stress was confirmed with the growth of the quantitative index of the $\mathrm{C}$-factor and a decrease in the predictive index of the success of composite restoration represeted the similar trend. The C-factor in the range of $0.3-2.3$ is not extremely critical in terms of the risk of microleakage formation between the composite and the tooth, as compared to indicators of the C-factor approaching 3.0.

Conclusions. The further development of a complex model of finite elements with the representation in its structure elements of a different density (in particular, enamels, dentin, various composites) and the corresponding mathematical argumentation of the polymerization shrinkage and stress vectors, will allow to objectivize the cumulative effect of the C-factor on the success of the composite restoration function, proceeding from the poly-directional stresses at the bonding interface of the composite material and tooth tissues interface.

Key words: C-factor; composite restoration; cavity configuration. 
Вступ. Розробка параметру конфігурації порожнини була обгрунтована потребою квантифікації співвідношення показників полімеризаційної усадки та полімеризаційного стресу відповідно до особливостей геометрії відпрепарованого каріозного дефекту. Класично С-фактор виражають як співвідношення кількості стінок реставрації, що контактує зі стінками зуба за рахунок бондингу, до кількості так званих вільних стінок, які не контактують із структурою зуба $[1,2]$. Виходячи 3 цього та особливостей механізму полімеризації сучасних композитних матеріалів, первинно було висунуто гіпотетичне припущення, що показник полімеризаційного стресу зростає паралельно зі збільшенням значення показника С-фактора. Одні з перших досліджень, направлені на визначення ролі С-фактора у прогнозі успішного функціонування реставрацій, були проведені А. J. Feilzer, який аналізував вплив варіації С-фактора, використовуючи циліндричні зразки реставрацій різної довжини та діаметра [3, 4]. В ході проведених експериментів вдалось встановити, що полімеризаційний стрес насправді зменшується зі зростанням показника С-фактора різних досліджуваних зразків. Однак за даними різних досліджень, рівень розподілу полімеризаційного стресу вираженіше залежить від абсолютних розмірів досліджуваних зразків реставрацій, а не безпосередньо від показника С-фактора, що проте не було достатньою мірою інтерпретовано 3 точки зору клінічної значимості отриманих результатів $[5,6]$.

Тому подальший аналіз впливу С-фактора на прогноз функціонування композитної реставрації шляхом виокремлення у структурі останніх параметрів полімеризаційної напруги, усадки та маргінальної адаптації $€$ актуальним науково-практичним питанням стоматології, що потребує відповідного вирішення.

Метою дослідження було проаналізувати вплив фактора конфігурації відпрепарованої порожнини на успішність функціонування прямих реставрацій у процесі розробки моделі прогностичної оцінки розподілу напруг на межі інтерфейсу композитного матеріалу та тканин зуба.

Матеріали і методи. 3 метою реалізації мети дослідження було проведено аналіз наукових публікацій з глибиною пошуку 10 років, завдання котрого полягало у наступному: виокремленні аспектів впливу фактора кон- фігурації порожнини на параметри полімеризаційної усадки та полімеризаційного стресу; визначенні відповідності застосовуваних підходів вивчення ролі С-фактора у прогнозі успішності функціонування прямих композитних реставрацій; пошуку нових підходів до інтеграції показників конфігурації, об’єму та топографії каріозної порожнини в єдину математичну модель, яка б передбачала можливості для аналізу розподілу стресових чинників залежно від типу застосовуваного матеріалу, специфіки його внесення та адаптації з метою подальшої профілактики сколів реставрації та її часткової або повної дезінтеграції.

Для проведення пошуку використовували форму пошуку Google Scholar (http://scholar. google.com) із застосуванням іï розширених функцій. У результаті застосування операторів «пошук за фразою» та «в заголовку» були сформовані наступні набори ключових слів: "C-factor», "dental cavity configuration», "cavity geometry", «direct restoration», "composite restoration», які використовували у різних комбінаціях. Кожний отриманий результат пошуку за комбінацією ключових слів являє собою набір академічних робіт відповідної тематики, які в подальшому підлягали контентаналізу.

Результати досліджень та їх обговорення. У своєму дослідження Z. Wang та M. Y. M. Chiang визначити С-фактор як дескриптор зняття напруги матеріалу, який є більш корелятивним до показника рівня полімеризаційного стресу, але не обов'язково до його амплітуди [7]. Кореляція між С-фактором та амплітудою полімеризаційного стресу є особливо залежною від сумісності використовуваної дослідницької системи 3 урахуванням специфіки геометрії порожнини та необхідності відновлення несучих структур зуба.

У дослідженні специфічної ролі С-фактора та об'єму реставрації на розвиток мікропідтікання та усадкової напруги між параметрами конфігурації порожнини та досліджуваними результуючими показниками не було відмічено явної лінійної асоціації $(\mathrm{r}=0,048, \mathrm{p}=0,6210)$. Однак значуща кореляція на рівні $\mathrm{r}=0,724$ була зареєстрована між об'ємом виконаної реставрації та прогресуванням мікропідтікання в експериментальних умовах [8]. При цьому R. R. Braga et al. (2006) відмітили, що дослідження впливу C-фактора на рівень мікропідтікання в експериментальних умовах є доцільним 
лише у випадках порівняння реставрацій однакового об’єму, оскільки останній параметр $€$ більш визначальним для зміни показників усадкового стресу [9].

D. C. Watts та J. D. Sattertwaite встановили, що хоча C-фактор і впливає на характер співвідношення однонаправлених усадки та стресу, однак останній показник залежить не тільки від величини С-фактора, а й від характеру його формування - специфічної геометрії порожнини [10]. Крім того, дослідники визначали наявність нелінійної залежності між параметрами висоти та діаметра досліджуваних композитних зразків відносно одноосьових полімеризаційних усадки та стресу. При цьому сервоконтрольовані моделі аналізу, на думку D. C. Watts та J. D. Sattertwaite, не являють собою необхідний варіант дизайну дослідження змін композиту, що відбуваються в ході його полімеризації, враховуючи варіативність геометрії каріозних порожнин [10]. Z. Wang та M. Y. M. Chiang також звернули увагу на проблему вибору відповідних методів дослідження для встановлення ролі параметра С-фактора на формування полімеризаційного стресу та полімеризаційної усадки. Автори відмітили, що загальноприйнятий тренд інтерпретації залежності змін С-фактора та похідних параметрів наступний: усадочний стрес зменшується при зростанні показника С-фактора [7]. Однак при виборі для дослідження несумісних або невідповідних систем аналізу такі тренди інтерпретації можуть варіювати, змінюючись в окремих випадках до абсолютно реверсивних.

A. Fok та W. A. Aregawi запропонували свою інноваційну тримірну модель дослідження параметра С-фактора виходячи із необхідності забезпечення сумісності запропонованого підходу різним клінічним та експериментальним умовам [5]. Дослідники обгрунтовували необхідність використовувати корекційний фактор як похідну функцію від С-фактора, а також коефіцієнта поперечної деформації та товщини пограничного шару досліджуваних зразків, з використанням яких можливо більш прогнозовано оцінювати розвиток полімеризаційного стресу. Такий підхід авторів був обгрунтований тим, що по суті стоматологічна реставрація являє собою складну за формою структуру, яка у різних ділянках піддається різному впливу сил стиснення та розтягу. Наприклад, поверхневий шар реставрацій піддають переважно площинним двоосьовим напругам, разом з тим, коли припульпарний шар - триосьовому впливу, який залежно від об'єму може взагалі не залежати від форми порожнини. Таким чином, стає зрозуміло, що розподіл стресу в структурі пломби є нерівномірним, і не може бути проаналізований виходячи лише із положення про С-фактор.

У дослідженні E. M. De Silca (2007) авторам вдалось встановити, що показник С-фактора на рівні 3,4 провокує розвиток мікропроміжку між композитом та тканинами зуба в усіх досліджуваних експериментальних зразках. Результати аналізу Стьюдента-НьюманаКейлса підтвердили статистично вищі показники формування мікрозазору між композитом та тканинами зубами при С-фактор=3,4 порівняно з показниками фактора конфігурації порожнини на рівнях 2,6 та 1,8 (p<0,0001) [11]. Більше того, при останніх показниках С-фактора формування мікрозазору відмічали лише в одному з усіх випадків кожної досліджуваної групи зразків, і різниця між такими не була статистично значимою $(\mathrm{p}>0,05)$. Результати інших суміжних досліджень також вказують на те, що показники С-фактора у діапазоні 0,3-2,3 є не настільки критичними, порівняно із такими, що наближаються до 3,0. У дослідженні Ю. В. Лахтіна та співавт. (2015) на основі використання моделі зуба та реставрації побудованої із скінчених елементів, дослідникам вдалось виявити, що при однонаправленому строго вертикальному навантаження на реставрований зуб I класу за Блеком, максимальне напруженні виникає в емалі на межі безпосереднього контакту. Таким чином, визначальними у подібних клінічних випадках є не лише вплив С-фактора (C=5), а й роль прецизійності адаптації реставрації уздовж збереженого контура емалі [12].

S. T. Armstrong et al. відмітили, що при порівнянні сили адгезії на відрив після нанесення та полімеризації ненаповненого бонду, даний показник виявився вищим у порожнинах із показниками С-фактора менше 0,5 (36,93 МПа та 32,68 МПа в періоди спостереження 30 та 150 днів), порівняно з порожнинами із показником С-фактора на рівні 2,5 (32,84 МПа та 15,46 МПа в періоди спостереження 30 та 150 днів) [13]. Проте таке зростання відбувалось нерівномірно між двома матеріалами, що свідчить про те, що склад, тип наповнювача, смоли та системи ініціатора композиту також визначають прогресування полімеризаційного стресу. Аналогічний результат було отримано і M. A. Ghulman (2011), який довів, що по- 
казники маргінальної адаптації силоранових матеріалів та мікрогібридних аналогів також змінюються залежно від зміни показника С-фактора [14]. Однак нульову гіпотезу дослідження, яка полягала у тому, що С-фактор не впливає на показники маргінальної адаптації силоранових матеріалів, була повністю спростована. Незважаючи на один із найменших показників полімеризаційної усадки, рівень маргінального прилягання Filtek Silorane також виявився залежним від параметрів С-фактора, хоч і меншою мірою, ніж рівень аналогічного досліджуваного критерію Filtek Z250. Рівень маргінального підтікання при показниках С-фактора $1 / 5$ становив $(0,030 \pm 0,067)$ мм, при С-фактор $=2 / 4-(0,031 \pm 0,070)$ мм, при С-фактор $=5 / 1-(0,104 \pm 0,149)$ мм [14]. При показниках С-фактора 3/3 та 4/2 у групі силоранів жодних ознак мікропідтікання не відмічали.

Таким чином, стає очевидним, що роль С-фактора у більшості досліджень була лише складовою у системі прогнозування розвитку полімеризаційного стресу. При моделюванні порожнини циліндричної форми, Т. Л. Рединову вдалось виявити, що в умовах, коли модуль пружності пломби складав близько половини модуля пружності зуба, критична ділянка концентрації напруги займала майже усю напівсферу реставрації, при урівноваженні параметрів модуля пружності - критична зона напруги зміщувалася ближче до центру напівсфери [15]. Таким чином, дослідники встановили, що при рівнозначності модулів пружності зуба та реставрації пружно-деформований стан одиниці зубного ряду та пломби розподіляється рівномірно, і не залежить від форми відпрепарованої порожнини. При цьому порожнини клиноподібної форми характеризуються більш високою концентрацією напруг порівняно з порожнинами циліндричної форми.

Дослідження, проведене Б. В. Ніштою (2014), яке було направлено на розробкукомп’ютерної моделі для чисельного аналізу напруженого стану зуба після реставрації каріозної порожнини, дозволило встановити, що форма останньої визначає характер сприйняття зубом механічного навантаження. Варіюючи розмір та форму пломби, що визначались геометрією порожнини, дослідники змінювали кількість кінцевих елементів саме в обсязі реставрації і встановили, що при їх кількості у 54142 - величина максимального навантаження становила 119 МПА (на 61 \% більше, ніж для зуба без пломби), при кількості 37335 - 105 МПА (на 42 $\%$ більше від інтактного зуба), при кількості 30719 - 89 МПА (на 42 \% більше, ніж для зуба без пломби) [16]. Очевидно, що таке підвищення характеру напруг на моделі зуба було пов'язане не тільки зі зростанням об'єму самої реставрації, а й відповідно зі зменшенням кількості власних інтактних тканин, а тому і $з$ підвищенням показника середнього рівня неоднорідності досліджуваної моделі, що врешті й спричиняє не тільки збільшення рівня концентрацій, а й їх міграцію із формуванням відповідних зон максимальної напруги на межі інтерфейсу з'єднання.

Я. М. Григоренко та співавт. (2011) запропонували власну біомеханічну модель та відповідний підхід аналізу на її основі впливу розмірів і локалізації каріозної порожнини на величину напруги в її ділянці [17]. Використовуючи підхід, запропонований авторами, та забезпечуючи на його основі апробації можливих варіантів реставрації дефекту (різними техніками, матеріалами із різними показниками жорсткості), можливо більш обгрунтовано підходити до процесу відновлення каріозних дефектів із прогнозуванням потенційних сколів, тріщин та зломів структури пломби та інтактних тканин зуба. Очевидно, що дана модель також може бути модифікована шляхом уведення в склад проміжного еластичного шару бонду та з подальшим урахуванням різниці у структурі пружності різних матеріалів, які використовують (СІЦ, текучих композитів).

Виходячи 3 вищенаведеного, стає зрозумілим, що для подальшого дослідження впливу геометрії відпрепарованої порожнини на якість виконаної реставрації необхідне використання математично-досконалих методів моделювання за типом методу кінцевих елементів. За даними Т. Л. Рединова та співавт., моделювання впливу геометрії порожнини на напружено-деформований стан зуба та реставрації складається із наступної поступовості етапів [15]:

1) чіткої верифікації параметрів поставленого завдання та формулювання розрахункової схеми дослідження;

2) розробки геометричної моделі, яка б підходила для аналізу методом кінцевих елементів;

3) сегментації сформованої моделі на сітку кінцевих елементів;

4) прикладення до сформованої та сегментованої моделі маргінальних значеннями 
умов дослідження у формі відповідних навантажень;

5) математичне вирішення системи сформульованих у результаті дослідження рівнянь;

6) аналіз отриманих результатів.

Специфіка дослідження конкретно параметра С-фактора у структурі моделі, сформованої із кінцевих елементів, полягає в тому, що досліднику фактично необхідно сформувати дві окремі об'ємні моделі, одна з яких репрезентуватиме зуб із порожниною, інша ж - реставрацію (об'єкт), яка буде виповнювати порожнину.

Висновки. У результаті проведеного аналізу впливу фактора конфігурації відпрепарованої порожнини на успішність функціонування прямих реставрацій вдалось систематизувати такі положення: 1) точність дослідження впливу С-фактора на параметри полімеризаційного стресу та полімеризаційної усадки залежать від відповідності розробленого дизайну дослідження та від урахування варіацій геометрії, топографії та об’єму каріозних порожнин; 2) виходячи із наведених літературних даних, підтверджено факт зменшення рівня усадкового стресу при зростанні кількісного показника С-фактора, та зниження прогностичного показника успішності композит-

\section{Список літератури}

1. Kleverlaan C. J. Polymerization shrinkage and contraction stress of dental resin composites / C. J. Kleverlaan, A. J. Feilzer // Dental Materials. - 2005. Vol. 21 (12). - P. 1150-1157.

2. Influence of polymerization mode and C-factor on cohesive strength of dual-cured resin cements / L. A. Jongsma, C. J. Kleverlaan, P. Pallav, A. J. Feilzer//Dental Materials. - 2012. - Vol. 28 (7). - P. 722-728.

3. Feilzer A. J. Increased wall-to-wall curing contraction in thin bonded resin layers / A. J. Feilzer, A. J. De Gee, C. L. Davidson // Journal of Dental Research. - 1989. Vol. 68 (1). - P. 48-50.

4. Feilzer A. J. Setting stresses in composites for two different curing modes / A. J. Feilzer, A. J. De Gee, C. L. Davidson // Dental Materials. - 1993. - Vol. 9 (1). P. 2-5.

5. Fok A. S. The two sides of the C-factor / A. S. Fok, W. A. Aregawi // Dental Materials. - 2018. - Vol. 34 (4). - P. 649-656.

6. Impact of quantity of resin, C-factor, and geometry on resin composite polymerization shrinkage stress in Class V restorations / A. L. S. Borges, A. B. Borges, T. A. Xavier [et al.] // Operative Dentistry. - 2014. - Vol. 39 (2). - P. 144-151.

7. Wang Z. Correlation between polymerization shrinkage stress and C-factor depends upon cavity compliance / Z. Wang, M. Y. Chiang // Dental Materials. - 2016. - Vol. 32 (3). - P. 343-352.

8 . The effects of cavity preparation and composite resin ної реставрації при аналогічній тенденції; 3) показники С-фактора у діапазоні 0,3-2,3 не $\epsilon$ гранично критичними 3 точки зору ризику формування мікропростору між композитом та стінкою зуба, порівняно з показниками С-фактора, що наближаються до 3,0; 4) при моделюванні напруг на структуру реставрації та зуба необхідно враховувати, що поверхневий шар реставрацій піддається переважно площинним двоосьовим напругам, разом з тим, як в товщі матеріалу розвиваються триосьові направлені стреси, які залежно від об'єму навколишнього композиту можуть взагалі не залежати від форми порожнини.

Перспективи подальших досліджень. Подальша розробка складної моделі скінчених елементів з репрезентацією у ї̈ структурі елементів різної щільності (зокрема емалі, дентину, різних композитних та прокладочних матеріалів) та відповідною математичною аргументацією векторів полімеризаційної усадки та стресу, дозволить об'єктивізувати кумулятивний вплив показника С-фактора на успішність функціонування композитної реставрації, виходячи із полінаправленості напруг на межі бондингового інтерфейсу композитного матеріалу та тканин зуба.

on bond strength and stress distribution using the microtensile bond test / S. S. L. Braga, L. R. S. Oliveira, R. B. Rodrigues [et al.] // Operative Dentistry. - 2018. Vol. 43 (1). - P. 81-89.

9. Experimental and FE displacement and polymerization stress of bonded restorations as a function of the C-Factor, volume and substrate stiffness / L. C. C. Boaro, W. C. Brandt, J. B. C. Meira [et al.] // Journal of Dentistry. - 2014. - Vol. 42 (2). - P. 140-148.

10. Watts D. C. Axial shrinkage-stress depends upon both C-factor and composite mass / D. C. Watts, J. D. Satterthwaite // Dental Materials. - 2008. - Vol. 24 (1). - P. 1-8.

11. The influence of C-factor, flexural modulus and viscous flow on gap formation in resin composite restorations / E. M. da Silva, G. O. Dos Santos, J. G. A. Guimarães [et al.] // Operative Dentistry. - 2007. - Vol. 32 (4). - P. 356-362.

12. Лахтін Ю. В. Моделювання напруженого стану твердих тканин зуба при реставрації каріозних порожнин І класу / Ю. В. Лахтін, Ю. В. Сміянов, Б. В. Нішта // Український стоматологічний альманах. - 2015. - № 4. - C. 9-12.

13. Armstrong S. R. The influence of water storage and C-factor on the dentin-resin composite microtensile bond strength and debond pathway utilizing a filled and unfilled adhesive resin / S. R. Armstrong, J. C. Keller, D. B. Boyer // Dental Materials. - 2001. - Vol. 17 (3). P. 268-276. 
14. Ghulman M. A. Effect of cavity configuration (C factor) on the marginal adaptation of low-shrinking composite: a comparative ex vivo study / M. A. Ghulman // International journal of dentistry. - 2011. P. 159749.

15. Трехмерное математическое моделирование напряженно-деформированного состояния зуба и пломбы / Е. Ю. Шелковников, А. И. Кириллов, С. М. Ефремов [и др.] // Ползуновский вестник. 2014. - № 2. - C. 54-58.

\section{References}

1. Kleverlaan, C.J., \& Feilzer, A. J. (2005). Polymerization shrinkage and contraction stress of dental resin composites. Dental Materials, 21 (12), 1150-1157.

2. Jongsma, L.A., Kleverlaan, C.J., Pallav, P., \& Feilzer, A.J. (2012). Influence of polymerization mode and C-factor on cohesive strength of dual-cured resin cements. Dental Materials, 28 (7), 722-728.

3. Feilzer, A.J., De Gee, A.J., \& Davidson, C.L. (1989). Increased wall-to-wall curing contraction in thin bonded resin layers. Journal of Dental Research, 68 (1), 48-50.

4. Feilzer, A.J., De Gee, A.J., \& Davidson, C.L. (1993). Setting stresses in composites for two different curing modes. Dental Materials, 9 (1), 2-5.

5. Fok, A.S., \& Aregawi, W.A. (2018). The two sides of the C-factor. Dental Materials, 34 (4), 649-656.

6. Borges, A.L.S., Borges, A.B., Xavier, T.A., Bottino, M.C., \& Platt, J.A. (2014). Impact of quantity of resin, C-factor, and geometry on resin composite polymerization shrinkage stress in Class $\mathrm{V}$ restorations. Operative Dentistry, 39 (2), 144-151.

7. Wang, Z., \& Chiang, M.Y. (2016). Correlation between polymerization shrinkage stress and C-factor depends upon cavity compliance. Dental Materials, 32 (3), 343352.

8. Braga, S.S.L., Oliveira, L.R.S., Rodrigues, R.B., Bicalho, A.A., Novais, V.R., Armstrong, S., Soares, C.J. (2018). The effects of cavity preparation and composite resin on bond strength and stress distribution using the microtensile bond test. Operative Dentistry, 43 (1), 81-89. 9. Boaro, L.C.C., Brandt, W.C., Meira, J.B.C., Rodrigues, F.P., Palin, W.M., \& Braga, R.R. (2014). Experimental and FE displacement and polymerization stress of bonded restorations as a function of the C-Factor, volume and substrate stiffness. Journal of Dentistry, 42 (2), 140-148. 10. Watts, D.C., \& Satterthwaite, J.D. (2008). Axial shrinkage-stress depends upon both C-factor and composite mass. Dental Materials, 24 (1), 1-8.

11. da Silva, E.M., Dos Santos, G.O., Guimarães, J.G.A., Barcellos, A.A.L., \& Sampaio, E.M. (2007). The influence of C-factor, flexural modulus and viscous flow on gap
16. Компьютерное моделирование и численный анализ напряженного состояния зуба после реставрации кариозной полости / Б. В. Ништа, Ю. В. Лахтин, Ю. В. Смеянов [и др.] // Журнал інженерних наук. - 2014. - № 3. - С. 7-12.

17. Математическое моделирование функциональной нагрузки при поражении твердых тканей зуба кариесом / Я. М. Григоренко, А. Я. Григоренко, М. Ф. Копытко [и др.] // Доповіді Національної академії наук України. - 2011. - № 8. - С. 177-182.

formation in resin composite restorations. Operative Dentistry, 32 (4), 356-362.

12. Laptin, Yu.V., Smiyanov, Yu.V., \& Nishta, B.V. (2015). Modelyuvannia napruzhenoho stanu tverdyh tkanyn zuba pry restavracii karioznyh porozhnyn I klasu [Simulation of the intense state of hard tooth tissues during restoration of carious cavities of the 1st class]. Ukrainskyi stomatolohichnyi almanah - Ukrainian Dental Almanac, 4, 9-12 [in Ukrainian].

13. Armstrong, S.R., Keller, J.C., \& Boyer, D.B. (2001). The influence of water storage and C-factor on the dentin-resin composite microtensile bond strength and debond pathway utilizing a filled and unfilled adhesive resin. Dental Materials, 17 (3), 268-276.

14. Ghulman, M.A. (2011). Effect of cavity configuration (C factor) on the marginal adaptation of low-shrinking composite: a comparative ex vivo study. International Journal of Dentistry, 159749.

15. Shelkovnykov, E.Yu., Kyryllov, A.Y., Efremov, S.M., Redynova, T.L., Tymofeev, A.A., \& Meteleva, T.Yu. (2014). Trehmernoe matematicheskoe modelirovanye napryazhenno-deformyrovannogo sostoyaniya zuba i plomby [Three-dimensional mathematical modeling of the stress-strain state of a tooth and filling]. Polzunovskyy vestnyk - Polzunovsky Bulletin, 2, 54-58 [in Russian].

16. Nyshta, B.V., Lahtyn, Yu.V., \& Smeyanov, Yu.V. (2014). Kompyuternoe modelirovanye i chyslennyy analiz napryazhennogo sostoyaniya zuba posle restavratsii karyoznoy polostiy [Computer modeling and numerical analysis of the stress state of a tooth after restoration of a carious cavity]. Zhurnal inzhenernykh nauk - Journal of Engineering Sciences, 3, 7-12 [in Russian].

17. Grygorenko, Ya.M., Grygorenko, A.Ya., Kopitko, M.F., Moskalenko, A.N., \& Homenko, L.A. (2011). Matematicheskoe modelirovanye funktsyonalnoy nagruzki pry porazhenii tverdykh tkaney zuba karyesom [Mathematical modeling of functional load in case of damage to hard tooth tissues by caries]. Dopovidi Natsionalnoi akademii nauk Ukrainy - Reports of the National Academy of Sciences of Ukraine, 8, 177-182 [in Russian].

Отримано 04.09.18 